\title{
Malicious legal transplants
}

\author{
Mathias Siems* \\ Durham Law School, Durham University, Durham, UK \\ *Author email: mathias.siems@durham.ac.uk
}

(Accepted 16 May 2017)

\begin{abstract}
It is frequently assumed that legal transplants can help law makers in choosing the best ideas from elsewhere in the world. However, this paper suggests that there can also be cases of 'malicious legal transplants'. It explains why such transplants emerge and how they may be prevented. This discussion fills a gap in the normative debate about legal transplants: while it is valuable to identify good models, it is equally important to understand how the impact of malicious ideas can be prevented.
\end{abstract}

Keywords: comparative law; legal transplants; diffusion of ideas; law and development; legislation

'If you dance with the devil, the devil doesn't change.

The devil changes you'

(8MM [film] 1999)

\section{Introduction}

It seems plausible to argue that learning from other countries can be valuable. For example, when a country suffers from economic hardship, ethnic tensions or any other problem, why not consider the experience from another country that has managed to overcome this problem? It is therefore frequently suggested that countries can benefit from legal transplants as far as they can identify legal rules that have already been successfully 'tested' abroad. ${ }^{1}$

However, some commentators also take a sceptical view of legal transplants. For example, it may be criticised that legal transplants often do not 'fit' well in the transplant country due to differences in the socio-economic context. ${ }^{2}$ Other critiques focus on the uneasy relationship between foreign rules and the domestic legal system and identify this as a problem of 'legal irritants' - or even claim that legal transplants are 'impossible'. ${ }^{3}$ Sometimes the criticism has also been directed against the substance of the transplanted rules, for example, due to political disagreements with certain positions of foreign ${ } \mathrm{w}^{4}$ or due to the diffusion of inefficient ideas. ${ }^{5}$

\footnotetext{
${ }^{1} \mathrm{R}$ Michaels 'Make or buy - a new look at legal transplants' in H Eidenmüller (ed) Regulatory Competition in Contract Law and Dispute Resolution (Munich: Beck, 2013) p 34; B Markesinis 'Our debt to Europe: past, present and future' in B Markesinis (ed) The Coming Together of the Common Law and the Civil Law (Oxford: Hart Publishing, 2000) p 61; K Zweigert and H Kötz An Introduction to Comparative Law (Oxford: Clarendon, 3rd edn, 1998) p 17.

${ }^{2} \mathrm{~A}$ point frequently raised about legal systems in transition: eg A Donaggio 'Limitations of legal transplants and convergence to corporate governance practices in emerging markets: the Brazilian case' in S Boubaker amd DK Nguyen (eds) Corporate Governance in Emerging Markets (Berlin: Springer, 2014) pp 465-484; J Jupp 'Legal transplants as tools for post-conflict criminal law reform: justification and evaluation' (2014) 3 Cambridge Journal of International and Comparative Law 381.

${ }^{3} \mathrm{G}$ Teubner 'Legal irritants: good faith in British law or how unifying law ends up in new divergences' (1998) 61 Modern Law Review 11; P Legrand 'The impossibility of legal transplants' (1997) 4 Maastricht Journal of European and Comparative Law 111.

${ }^{4}$ See eg the debate in the US: OJ Benvenuto 'Reevaluating the debate surrounding the Supreme Court's use of foreign precedent' (2006) 38 Fordham Law Review 2596.

${ }^{5} \mathrm{E}$ Carolan 'Diffusing bad ideas: what the migration of the separation of powers means for comparative constitutionalism and constitutional transplants' in S Farran, J Gallen and C Rautenbach (eds) The Diffusion of Law (Farnham: Ashgate, 2015) pp $213-233$. 
This paper introduces another type of legal transplants, namely those that can be seen as 'malicious'; for example, transplants that are harmful to the, previously intact, social coexistence of different groups in society. ${ }^{6}$ The lack of research dealing with such transplants may be explained by the aim of mainstream comparative law to provide policy recommendations, and thus a bias for legal models perceived as good. However, as this paper will explain, there is also a need to study malicious legal transplants, notably in order to understand whether and how it may possible to prevent them.

The structure of the argument is as follows: Section 1 sets the scene of the proposed new topic of malicious legal transplants. It provides examples that illustrate the meaning and scope of this concept. It also outlines the debate about legal transplants and diffusion, given that some of the previous lines of research can be helpful in the understanding of malicious legal transplants. On this basis, Section 2 develops an evaluative framework for malicious legal transplants. It identifies the main determinants for the occurrence of malicious legal transplants, leading to suggestions on how, at least in some circumstances, it may be possible to prevent them. Section 3 concludes with general reflections about the research on legal transplants as it identifies either good models or, indeed, malicious ones.

\section{Setting the scene: malicious and non-malicious legal transplants}

The notion of 'malicious legal transplants' is a new one, but it can also be related to other types of legal transplants. Thus, this section discusses, first, how this new notion can be understood, and secondly, how it is related to previous research which deals with (mainly) non-malicious forms of legal transplants and policy diffusion.

\section{(a) The notion of 'malicious legal transplants'}

This paper does not suggest a closed definition of 'malicious legal transplants'. Yet, as a starting point, it is helpful to explain, tentatively, how 'legal transplants' in general and 'malicious legal transplants' in particular may be defined. The subsequent text introduces three examples which will be seen as core cases of 'malicious legal transplants'. Finally, it is contemplated which further cases may be conceivable.

\section{(i) A tentative definition of '(malicious) legal transplants'}

Alan Watson is often seen as the founding father of the concept of legal transplants. ${ }^{7}$ Watson's view is shaped by being a legal historian and Roman lawyer, in particular his insight that the private law of many countries is significantly based on the reception of Roman law. Here Watson found that 'borrowing, even mindless, is the name of the legal game'. ${ }^{8}$ Such borrowing is not limited to legal rules, since the transplant of Roman law also concerned legal institutions and structures. ${ }^{9}$ Thus, according to Watson, it shows that rules and concepts 'can survive without any close connection to any particular people, any particular period of time or any particular place'. ${ }^{10}$

In the contemporary literature on legal transplants it is also said that the object of a legal transplant can be diverse. Often it is the (mere) text of a particular statute law, ${ }^{11}$ but recently there have also been extensive discussions about citations to foreign judgments in court decisions. ${ }^{12}$ Beyond legal texts,

\footnotetext{
${ }^{6}$ For details and examples of this category see Section 1 (a), below.

${ }^{7}$ A Watson Legal Transplants: An Approach to Comparative Law (Athens, GA: University of Georgia Press, 2nd edn, 1993; 1st edn, 1971). But see also JW Cairns 'Watson, Walton and the history of legal transplants' (2013) 41 Georgia Journal of International and Comparative Law 637.

${ }^{8}$ A Watson Law, Society, Reality (Lake Mary, FL: Vandeplas, 2007) p 5.

${ }^{9}$ A Watson 'The importance of "nutshells"' (1994) 42 American Journal of Comparative Law 1, 2.

${ }^{10}$ A Watson 'Legal transplants and law reform' (1996) 92 Law Quarterly Review 79, 81.

${ }^{11}$ So, this refers to 'legislative comparative law'; see Zweigert and Kötz, above n 1, p 51.

${ }^{12}$ See eg M Gelter and M Siems 'Citations to foreign courts - illegitimate and superfluous, or unavoidable? Evidence from Europe’ (2014) 62 American Journal of Comparative Law 35.
} 
today, the main aim is often to transfer particular ideas or policies; for example, the idea of having codified state law or spreading the idea of the Western model of human rights to other parts of the world. ${ }^{13}$ Going further, elements related to a country's legal culture can also be transplanted: though these elements - such as legal education, methods and mentalities - cannot be changed overnight, most comparative lawyers agree that, here too, foreign models can be used. ${ }^{14}$

Moreover, there is diversity as regards the circumstances that can lead to a transplant. In the literature, frequent examples concern the influence of Western laws in colonial times and the copying of modern business laws across the world more recently. ${ }^{15}$ This shows that legal transplants can be of an involuntary or a voluntary nature. It is also possible that the process leading to a legal transplant is less deliberate and more fluid, whereby a common language and legal culture influence intellectual exchange: ${ }^{16}$ thus, here, terms such as 'legal circulation', 'cross-fertilisation', 'diffusion' or 'migration, ${ }^{\text {'17 }}$ may be used in order to describe this type of legal transplant.

For 'malicious legal transplants' it follows that they can also concern any legal object and be either of an involuntary or a voluntary nature. In addition, in order to be 'malicious' there needs to be intention to do harm. Thus, 'malicious legal transplants' have an objective element ('harm'), for example, where one group in society imposes its social norms on another one without need (as will be shown in the next section). In addition, the subjective element means that at least one actor of the transplant process recognises the use of the transplant in such a manner. Thus, this is different from a situation where a legal transplant merely does not work well due to some kind of unintended consequence. This specific character of 'malicious legal transplants' can also be seen in the following three examples.

\section{(ii) Examples of 'malicious legal transplants'}

In many countries of the world, multiple ethnicities live peacefully together. But throughout human history there have also been periods of racially motivated laws with a malicious effect. In some instances, those laws were a product of legal transplants. For example, it has been suggested - but without certainty - that the US racial segregation laws of the nineteenth century seemed to have influenced the laws of racial identification and purity in Nazi Germany. ${ }^{18}$ With more confidence it can be said that the Nazi laws influenced the laws of Mussolini's Italy. There is some scholarly disagreement about the factors accounting for the Italian racial politics under Fascism. Some scholars emphasise internal developments, for example referring to the impact of rules about the relationship between Italians and the local population in the Italian colonies as well as the fact that Italy had a more cultural (as opposed to purely racial) definition of Jewishness. ${ }^{19}$ But scholars often also make reference to the German influence on the Leggi Razziali of 1938:

\footnotetext{
${ }^{13}$ See eg J-L Halpérin 'The concept of law: a Western transplant?' (2010) 10 Theoretical Inquiries in Law 333; BA Simmons Mobilizing Human Rights: International Law in Domestic Politics (Cambridge: Cambridge University Press, 2009).

${ }^{14}$ For different forms and objects of legal transplants, see eg W Twining General Jurisprudence: Understanding Law from a Global Perspective (Cambridge: Cambridge University Press, 2009) p 279.

${ }^{15}$ Summary in M Siems Comparative Law (Cambridge: Cambridge University Press, 2nd edn, 2018) pp 251-255. See also Section 1 (b) (i), below.

${ }^{16}$ For a specific example: H MacQueen 'Scotland' in Jan M Smits (ed) Elgar Encyclopaedia of Comparative Law (Cheltenham: Edward Elgar, 2nd edn, 2012) p 791.

${ }^{17}$ For the different terms, see eg V Perju 'Constitutional transplants, borrowing, and migrations' in M Rosenfeld and A Sajo (eds) The Oxford Handbook of Comparative Constitutional Law (Oxford: Oxford University Press, 2012) pp 1306-1308.

${ }^{18} \mathrm{~B}$ Ezzell 'Laws of racial identification and racial purity in Nazi Germany and the United States: did Jim Crow write the laws that spawned the Holocaust?' (2002) 30 Southern University Law Review 1. For further details on the US history, see RF Moran, 'Love with a proper stranger: what anti-miscegenation laws can tell us about the meaning of race, sex, and marriage' (2004) 32 Hofstra Law Review 1663.

${ }^{19}$ MA Livingston The Fascists and the Jews of Italy: Mussolini's Race Laws, 1938-1943 (Cambridge: Cambridge University Press, 2014); JD Zimmerman (ed) Jews in Italy under Fascist and Nazi Rule, 1922-1945 (Cambridge: Cambridge University Press, 2005); O De Napoli 'The origin of the racist laws under fascism: a problem of historiography' (2012) 17 Journal of Modern Italian Studies 106. Those views were also promoted through the Fascist journal La difesa della razza.
} 
Italian laws were more or less an imitation of Nazi Germany. In 1937, Mussolini 'saw the political usefulness of anti-Semitism, and his views developed rapidly in 1938 as he moved closer to a German alliance'. The introduction of a body of legislation against the Jews was 'his own spontaneous decision to show solidarity with Nazism.' His cynicism toward a move conceived as 'merely tactical' was unmistakable. Mussolini was not a long-time anti-Semite nor was he an anti-Semite by conviction, but rather was driven by cynical considerations of opportunism: 'though he personally thought the idea of racial purity was nonsense, it was politically expedient that others should think differently.'20

Another example concerns the spread of religious laws that do not simply codify certain practices for believers, but impose those on members of other religious and non-religious groups. Saudi Arabia, for example, bans non-Muslim places of worship as well as the importation of non-Muslim religious materials and 'haram' food such as pork, all monitored by a religious police force. In recent decades some of those religious laws have spread to other countries - directly or more indirectly through the funding of Wahhabi educational, charitable and religious institutions. The international impact can then be seen, for example, in restrictions to the legal profession to non-Muslims in northern Nigeria $^{21}$ and the possible application of a strict Sharia law to non-Muslims in Brunei ${ }^{22}$ and in the Indonesian province of Aceh. ${ }^{23}$ The Maldives also provides a specific example of such changes:

[S]ince Islam was introduced in the Maldives in the 12th century, religious practices in the country have been moderate. Yet ... in 1994, the Protection of Religious Unity Act was passed, which restricted the freedom to practice any other religion besides Islam. In 1996, Gayoom constituted the Supreme Council for Islamic Affairs (which was renamed the Ministry of Islamic Affairs in 2008) charged with overseeing religious affairs in the country. This body of clerics pressured the government to carry out moral and cultural policing of alleged 'anti-Islamic activities.' In 2008, it asked the police to ban night clubs and discotheques for New Year's Eve celebrations, saying that they were contrary to Islam. In May 2010 ... new legislation prohibited 'talking about religions other than Islam in Maldives, and propagating such religions,' as well as reinforcing that it is illegal 'to use any kind of medium to propagate any religion other than Islam' .... . ${ }^{24}$

Those new laws were, to a large extent, the result of foreign influence: from Saudi Arabia, but also through Maldivian students attending madrasas in Pakistan. ${ }^{25}$

The third example is about the criminalisation of homosexual acts through British colonial law. In pre-colonial India - as well as in most other colonies - there may have been social rejection, or perhaps a small fine, but no criminal sanctions for homosexual acts. ${ }^{26}$ This changed with s 377 of the Indian Penal Code of 1860, dealing with the 'carnal intercourse against the order of nature' and codifying the British 'buggery law'. ${ }^{27}$ This provision was then also adopted by other British colonies, with

\footnotetext{
${ }^{20}$ De Napoli, ibid, p 117 (discussion of the position of Denis Mack Smith and other historians).

${ }^{21}$ P Marshall (ed) The Talibanization of Nigeria: Sharia Law and Religious Freedom (Washington, DC: Freedom House, 2002).

${ }^{22}$ Deutsche Welle Religion Sharia in Brunei: The Sultan's New Laws (10 May 2014), available at http://www.dw.com/en/ sharia-in-brunei-the-sultans-new-laws/a-17627008.

${ }^{23} \mathrm{C}$ Chaplin 'Imagining the land of the two holy mosques: the social and doctrinal importance of Saudi Arabia in Indonesian Salafi discourse' (2014) 7 Austrian Journal of South-East Asian Studies 217; A Kovacs Saudi Arabia Exporting Salafi Education and Radicalizing Indonesia's Muslims (2014) GIGA Focus, available at www.giga-hamburg.de/en/system/ files/publications/gf_international_1407.pdf.

${ }^{24}$ A Roul 'The threat from rising extremism in the Maldives' (2013) 6/3 CTC Sentinel 24-28 (footnotes omitted).

${ }^{25}$ Ibid. See also A Singh Ningthoujam Maldives is No Longer a 'Paradise' (2 April 2015), available at www.ict.org.il/Article/ 1372/Maldives-is-No-Longer-a-Paradise.

${ }^{26}$ See R Vanita and S Kidwai (eds) Same-Sex Love in India, Readings in Indian Literature (New York: Palgrave, 2001$)$ p 25.

${ }^{27} \mathrm{D}$ Sanders '377 and the unnatural afterlife of British colonialism in Asia' (2009) 4 Asian Journal of Comparative Law 1.
} 
Malaysia and Singapore adding a further s 377A that also criminalised homosexual acts not covered by s 377. Thus, as a result,

19th century codifications of British criminal law ... criminal prohibitions of homosexual acts came into force in all 'common law' jurisdictions. The lead role in this process was played by the Indian Penal Code, a one-size-fits-all model code. This occurred in a period in which parallel prohibitions were eliminated in the other major European colonial powers ... . ${ }^{28}$

One or both of these provisions have been retained in many of the former British colonies. ${ }^{29}$ Since the actual behaviour covered by these provisions can often not be proven, this can be interpreted as a general means to discriminate against homosexuals. ${ }^{30}$

\section{(iii) Common ground and possible extensions}

The three examples have in common that the prior position of the transplant country was receptive towards differences in race, religion and sexual orientation. This situation is therefore different from the type of legal transplants, more frequently discussed in the literature, where the traditional culture of the transplant country had been prejudiced towards the behaviour that the transplant aimed to introduce; for example, transplants that aimed to liberalise family law in terms of allowing no fault divorce or introducing same-sex unions. ${ }^{31}$

More specifically, the 'maliciousness' of the legal transplant in the three examples follows from the change of the status quo to a situation where one group in society imposes its social norms on another one without need. While societies require some common rules, it is not justifiable to intervene in religious, sexual and other practices that do not pose any harm to other groups in society. ${ }^{32}$ Such transplants are therefore particularly harmful for diverse societies where law needs to facilitate the coexistence of different groups. Thus, in these situations the problem is not simply the underlying idea but the fact that the legal change is designed with malicious intentions in mind.

Since 'malicious legal transplants' are a new concept, it is, however, not suggested that there may not also be other categories of such transplants. A first of those may concern examples where the policy orientation of the imported law is rejected. For instance, it may be argued that, in recent decades, we have observed how a 'neoliberal' Anglo-Saxon business law has, maliciously, spread to social-democratic countries in Europe. ${ }^{33}$ Or, it may be argued that it was 'liberal' European ideas, such as a system of national healthcare, that have 'infected' US law. ${ }^{34}$ Or, within Europe, perhaps the case-law of the European Court of Human Rights has been harmful to the UK legal system in requiring it to provide voting rights to prisoners and in restricting the ability to deport foreign criminals to their home countries. ${ }^{35}$

A second category would be more specific about the effect in the transplant country. In the discourse about the relationship between law and development, it is often argued that the influence of

\footnotetext{
${ }^{28}$ Ibid, pp 14-15.

${ }^{29}$ See Human Rights Watch 'This alien legacy: the origins of “sodomy” laws in British colonialism' in C Lennox and M Waites (eds) Human Rights, Sexual Orientation and Gender Identity in the Commonwealth: Struggles for Decriminalisation and Change (London: Institute of Commonwealth Studies, 2013) pp 83-123.

${ }^{30}$ Ibid, p 110.

${ }^{31}$ See eg L Friedman 'Some comments on Cotterrell and legal transplants' in D Nelken and J Feest (eds) Adapting Legal Cultures (Oxford: Hart, 2001) pp 93-98, with 'no fault divorce' as an example; MF Moscati Pasolini's Italian Premonitions: Same-Sex Unions and the Law in Comparative Perspective (London: Wildy, Simmonds and Hill, 2014).

${ }^{32}$ MC Nussbaum "Equal respect for conscience": Roger Williams on the moral basis of civil peace' (2007) 15 Harvard Review of Philosophy 4, 14 (with reference to Locke).

${ }^{33}$ For the debate, see eg G Schnyder and M Siems 'The ordoliberal variety of neoliberalism' in S Konzelmann and M Fovargue-Davies (eds) The Faces of Liberal Capitalism: Banking Systems in Crisis (London: Routledge, 2013) pp 250-268.

${ }^{34}$ Eg S Gregg Becoming Europe: Economic Decline, Culture, and How America Can Avoid a European Future (New York: Encounter Books, 2013).

${ }^{35}$ Eg M Pinto-Duschinsky Bringing Rights. Back Home. Making Human Rights Compatible with Parliamentary Democracy in the UK (London: Policy Exchange, 2011).
} 
Western legal ideas has been harmful to countries of the developing world, for example, because 'Western laws' that protect property rights may be counterproductive when corruption and income disparity mean that these laws are mainly used by the current elites to the detriment of the poor. ${ }^{36}$ Such reasoning can also be related to the frequent general view that much of the Western influence in the world has been harmful, characterising it as 'a tale of cross-contamination, the spread of bad ideas. ${ }^{37}$

But these two further categories can also be seen as problematic, since not everyone may regard these transplants as malicious. With respect to differences in policy orientation, there is bound to be disagreement about the value and precise balance of such goals. It is also not always clear whether the lack of a transplant's 'fit' is really something negative since some transplants have the explicit aim of stimulating changes in the society in question. ${ }^{38}$ And, more generally, as legal philosophy and jurisprudence discuss various normative theories of justice and injustice, ${ }^{39}$ it is clear that there cannot be full agreement about a positive or negative assessment of a particular transplant.

For the purposes of this paper, however, this 'fuzziness' is not a problem. It is only necessary that normative positions are possible. Thus, for anyone who does not subscribe to a radical relativist position, there will be situations where particular rules are seen as not only technically flawed but 'malicious' - and there is therefore the need to understand such cases in more detail.

\section{(b) Research context: legal transplants and diffusion of ideas}

While the concept of 'malicious legal transplants' is a new one, it can also be related to previous research in law and other disciplines. The second part of this section will therefore outline the positive and the normative research about legal transplants in comparative law as well as the research on the diffusion of ideas and policies, thus setting the scene for the evaluative framework of the subsequent sections.

\section{(i) Positive research in comparative law}

The beginning of this paper mentioned that legal transplants often aim to use ideas that have been successfully 'tested' abroad. This is indeed a frequently mentioned reason why legal transplants are said to occur. ${ }^{40}$ Thus, here, transplants are driven by the transplant country, which deliberately adopts a good legal rule (or legal institution) from another country. In addition, it has the benefit that copying a foreign law saves law makers the costs of drafting an original law on their own. ${ }^{41}$

More subjective are transplants that reflect the internal preferences and interests of the transplant country. For example, as law makers cannot evaluate the potential benefits of all countries of the world, they will choose a foreign model that the general public perceives to be the most legitimate one. It is also likely that interest groups of the transplant country will shape the choice of the model that is most favourable to them. ${ }^{42}$

With respect to the aspired benefits for the origin country, a country can, for example, benefit from its laws being transplanted, since a familiar legal system makes it easier for its firms to do business with firms from the transplant country (ie it reduces transaction costs). If other countries follow the values

\footnotetext{
${ }^{36} \mathrm{Eg}$ U Mattei and L Nader Plunder: When the Rule of Law is Illegal (Oxford: Wiley-Blackwell, 2008).

${ }^{37}$ I Buruma and A Margalit Occidentalism: The West in the Eyes of its Enemies (New York: Penguin, 2004$)$ p 149.

${ }^{38} \mathrm{D}$ Nelken 'Comparatists and transferability', in P Legrand and R Munday (eds) Comparative Legal Studies: Traditions and Transitions (Cambridge: Cambridge University Press, 2003) p 456 ('geared to fitting an imagined future').

${ }^{39}$ See eg MJ Sandel (ed) Justice: A Reader (New York: Oxford University Press, 2007); E Heinze The Concept of Injustice (Abingdon: Routledge, 2013).

${ }^{40}$ For the following, see Siems, above n 15, pp 233-236 (with further references).

${ }^{41}$ JM Miller 'A typology of legal transplants: using sociology, legal history, and Argentine examples to explain the transplant process' (2003) 51 American Journal of Comparative Law 839, calls those 'cost-saving transplants' (p 845).

${ }^{42}$ Miller ibid, as 'legitimacy-generating' ( $p$ 854) and 'entrepreneurial' transplants (p 849).
} 
of the origin countries, the latter benefits from the 'prestige' of having an influential legal system - and this can also have tangible benefits: for instance, foreign lawyers who want to buy literature about this legal system, or pay to study at its universities. ${ }^{43}$

Another crucial consideration is the power relationship between the two countries. From the perspective of the transplant country, transplants can be ordered by the extent to which it still enjoys de facto sovereignty regarding the transplant decision, distinguishing between imposition, transnational commitment, external pressure, prestige generated and voluntary adoption. ${ }^{44}$ From the perspective of the origin country, the transplant can be a result of soft power or forms of 'legal imposition' or even 'legal imperialism'. ${ }^{45}$ These forms of transplants can be related to examples from history, such as the colonial influence of Western powers. As a form of 'neo-imperialism' they are also said to be a common feature of many developments today, for example, through the influence of the World Bank's Doing Business Reports on the business laws of transition and developing countries. ${ }^{46}$

All of these latter considerations show that even in current legal research it is not seen as a matter of course that transplants are simply the result of a search for 'better law'. These considerations will become relevant again when this paper turns to the reasons why, sometimes, even malicious legal transplants occur. ${ }^{47}$

\section{(ii) Normative research in comparative law}

In the normative research about legal transplants, a helpful division is between optimists and pessimists (while intermediate positions are also widespread). ${ }^{48}$ The optimists argue that legal transplants can help countries to address major economic and social problems. Thus, we are told that comparative lawyers should aim to 'increase intellectual interaction and borrowings', denouncing opposition as 'parochialism'. ${ }^{49}$ The practicality of transplants is not doubted, since most, if not all, legal systems have managed to incorporate ideas from various parts of the world: in other words, 'no legal system is entirely a prisoner of its own past traditions ${ }^{5}{ }^{50}$ Such a position is also supported by economists and development organisations as they often regard it as crucial to implement successful legal models from other countries in order to stimulate a country's development. ${ }^{51}$

The pessimists object that, in practice, legal transplants are often unfavourable to the incoming legal system. Two variants of such a view can be distinguished. On the one hand, the criticism can refer to the relationship between the transplanted and the previous law. Thus, it may be argued that foreign ideas have 'polluting or disrupting effects' on the domestic legal order ${ }^{52}$ and that, therefore, legal transplants should really be called 'legal irritants' ${ }^{53}$ On the other hand, the negative effect may refer to the relationship between the transplanted law and the social, economic, cultural and political environment. Taking the view that there are complementarities between the law, society, culture and political

\footnotetext{
${ }^{43}$ See eg the recent 'battle of brochures' discussed in H Kötz 'The jurisdiction of choice: England and Wales or Germany?' (2010) 18 European Review of Private Law 1243.

${ }^{44} \mathrm{M}$ Cohn 'Legal transplant chronicles: the evolution of unreasonableness and proportionality review of the administration in the United Kingdom' (2010) 58 American Journal of Comparative Law 583, 591 (in addition referring to negative fertilisation and novation).

${ }^{45}$ See eg U Mattei 'A theory of imperial law: a study of U.S. hegemony and the Latin resistance' (2003) 10 Indiana Journal of Global Legal Studies 383.

${ }^{46}$ For examples see Siems, above n 15, pp 223, 354-357.

${ }^{47}$ Section 2 (a), below.

${ }^{48}$ See overview in Siems, above n 15, pp 255-259.

${ }^{49}$ Markesinis, above n 1, p 49; E Buscaglia and W Ratli Law and Economics in Developing Countries (Stanford, CA: Hoover Institution, 2000) p 31.

${ }^{50}$ TT Arvind 'The "transplant effect" in harmonization' (2010) 59 International and Comparative Law Quarterly 65, 81.

${ }^{51}$ For a summary, see MJ Trebilcock and MM Prado Advanced Introduction to Law and Development (Cheltenham: Edward Elgar, 2014) pp 45-55.

${ }^{52} \mathrm{HC}$ Gutteridge Comparative Law: An Introduction to the Comparative Method of Legal Study and Research (Cambridge: Cambridge University Press, 1946) p 25.

${ }^{53}$ Teubner, above n 3.
} 
process of each country, ${ }^{54}$ it follows that one should not simply copy laws from abroad. Thus, according to this view, legal transplants often fail, for instance, due to lack of enforcement, side-lining or general unsuitability. ${ }^{55}$

Sometimes the criticism is also directed against the more general idea of the transplanted law, thus shifting the criticism closer to the notion of transplants that some may regards as 'malicious'. A prominent example concerns human rights. According to 'cultural relativists', the Western origins of human rights mean that they should not be imposed on other cultures. ${ }^{56}$ For example, it is argued that formal legal rights may not be appropriate for societies in Africa and the Middle East, which are based on kinship and other group-centred social structures, and where law and religion are not strictly separated. It has also been said that 'Asian values' may be irreconcilable with human rights, for instance referring to the collectivist and communitarian principles in Asian culture.

\section{(iii) Research on diffusion of ideas and policies}

At a general level, the legal transplant literature can be related to research dealing with the evolution of ideas and other cultural 'units'. Such research can be of a historical nature, ${ }^{57}$ but the growing field of 'futures studies' also explores possible development trends in the coming decades and centuries. ${ }^{58}$ Theories of 'cultural selection' often pursue a more theoretical angle, using evolutionary concepts. ${ }^{59}$ Related to such research is also the theory of 'memetics' which analyses how far units of culture ('memes') evolve similarly to Darwinian principles. ${ }^{60}$

More specifically, legal transplants can be linked to research on the diffusion of innovations. A book by Everett Rogers is often cited as the work that most clearly explains what accounts for the adoption of an innovative idea or technology. According to Rogers, an innovation succeeds if it (i) has a relative advantage over existing ideas or technologies, (ii) is compatible with the adopter's preconditions, (iii) has a low level of complexity, (iv) allows a system of trial and error and (v) has observable benefits. ${ }^{61}$ But it is also clear that these five factors are not the only possible determinants for the adoption and implementation of particular innovations. For example, for complex phenomena, it can be important to break down innovations into manageable parts and adopt them on an incremental basis. ${ }^{62}$

In the political science literature, a similar discussion concerns the conditions for the transferability of policies. It is said that the countries involved need to be ideologically and psychologically compatible. Thus, there needs to be agreement on basic policy objectives and values (for example, whether and how social welfare is provided) and to consider that resistance against a policy can arise both at the level of the government and of the general public. ${ }^{63}$ Political science has also

\footnotetext{
${ }^{54}$ See eg B Ahlering and S Deakin 'Labour regulation, corporate governance and legal origin: a case of institutional complementarity?' (2007) 41 Law \& Society Review 865.

${ }^{55}$ NHD Foster, 'Comparative commercial law: rules or context?' in E Örücü and D Nelken (eds) Comparative Law: A Handbook (Oxford, Hart Publishing, 2007) pp 273-274. See also D Berkowitz, K Pistor and J-F Richard 'The transplant effect' (2003) 51 American Journal of Comparative Law 163.

${ }^{56}$ For a summary of the discussion, see P Alston and R Goodman International Human Rights (Oxford: Oxford University Press, 2012) pp 531-557.

${ }^{57}$ The main journal is the Journal of the History of Ideas.

${ }^{58}$ See eg the main associations: the World Future Society (www.wfs.org), the World Futures Studies Organisation (www. wfsf.org) and the Association of Professional Futurists (www.profuturists.org).

${ }^{59}$ GKD Crozier 'Reconsidering cultural selection theory' (2008) 59 British Journal for the Philosophy of Science 455.

${ }^{60} \mathrm{R}$ Dawkins The Selfish Gene (Oxford: Oxford University Press, 2nd edn, 1989). For an application to law, see S Deakin 'Evolution for our time: a theory of legal memetics' (2002) 55 Current Legal Problems 1.

${ }^{61}$ E Rogers Diffusion of Innovations (New York: Free Press, 5th edn, 2003).

${ }^{62}$ See T Greenhalgh, G Robert and P Bate How to Spread Good Ideas - A Systematic Review of the Literature on Diffusion, Dissemination and Sustainability of Innovations in Health Service Delivery and Organisation (Report for the National Co-ordinating Centre for NHS Service Delivery and Organisation R\&D, April 2004) pp 15, 142. See also W Twining 'Social science and diffusion of law' (2005) 32 Journal of Law and Society 203, 217-220 (sceptical about the suitability of Rogers' diffusion theory).

${ }^{63}$ For a summary see L Hantrais International Comparative Research: Theory, Methods and Practice (Basingstoke: Palgrave, 2009) pp 133-139.
} 
been interested in different mechanisms for policy transfers: the main emphasis has been on processes of learning and mimicking but it has also analysed coercive and competitive mechanisms. $^{64}$

These lines of research have their main interest in the diffusion of 'good' ideas (including good technologies and policies). By contrast, a book by the late French sociologist Raymond Boudon has, in translation, the title 'Ideology: the origin and diffusion of mistaken ideas' ${ }^{65}$ Boudon takes the position that these mistaken ideas are not due the irrationality of the actors, but rather that rational actors follow these ideas as 'black boxes' due to reasons of 'social position, cultural disposition, and historical situation'. ${ }^{66}$ For his main examples Boudon refers to mainstream theories of economic development, but also dependency theory. Similar is a book by the heterodox economist John Quiggin on 'zombie economics'. Quiggin argues that many 'dead economic ideas still walk among us', for example referring to the notion about the efficiency of capital markets after the global financial crisis of 2008 . $^{67}$

A problem with these two books may be that readers who do not share Boudon's and Quiggin's criticism of these theories may well find that their core cases are not actually negative ones. However, it is also possible to present clearer 'malicious' examples, some of them related to the legal examples of the previous section. While an example from a history review discusses the 'spread of intolerance, absolutism, and racism in early modern Europe', ${ }^{68}$ the main cases derive from the twentieth and early twenty-first centuries. For instance, reference can be made to publications that deal with similarities between Nazism and Stalinism, ${ }^{69}$ the spread of the demonisation of China in the Western media, ${ }^{70}$ the spread of 'genocide ideology' in Rwanda and neighbouring African countries, ${ }^{71}$ as well as the spread of 'Al-Qaedaism' and 'Islamic fascism'. ${ }^{72}$ This last example can also be related to another general field of discussion, namely whether the Internet, notably social networks such as Twitter, are really beneficial - in the sense of the 'wisdom of crowds $^{73}$ - or whether it is rather the case that they strengthen previously isolated extremist positions. $^{74}$

\section{Evaluative framework for malicious legal transplants}

On the basis of the considerations of the previous section, it is now possible to develop a conceptual framework for malicious legal transplants. For this purpose, the following will distinguish between the object of the transplant, the transplant process and the dynamics in the transplant country in such scenarios. As Table 1 illustrates, these topics are then applied to the questions about the determinants for the occurrence of malicious legal transplants in the first subsection, and to the means with which malicious legal transplants may be prevented in the second one.

\footnotetext{
${ }^{64} \mathrm{JL}$ Campbell 'Institutional reproduction and change' in G Morgan et al (eds) The Oxford Handbook of Comparative Institutional Analysis (Oxford: Oxford University Press, 2010) pp 97-106.

${ }^{65} \mathrm{R}$ Boudon, L'idéologie ou L'origine des idées reçues (Paris: Fayard, 1986).

${ }^{66}$ As phrased in the review by J Herf (1989) 18 Contemporary Sociology 291.

${ }^{67} \mathrm{~J}$ Quiggin Zombie Economics: How Dead Ideas Still Walk among Us (Princeton, NJ: Princeton University Press, 2010).

${ }^{68} \mathrm{GV}$ Scammell 'Essay and reflection: on the discovery of the Americas and the spread of intolerance, absolutism, and racism in early modern Europe' (1991) 13 International History Review 502.

${ }^{69}$ TD Snyder Bloodlands: Europe between Hitler and Stalin (New York: Basic Books, 2010).

${ }^{70} \mathrm{R}$ Mayer Serial Fu Manchu: The Chinese Supervillain and the Spread of Yellow Peril Ideology (Philadelphia, PA: Temple University Press, 2013).

${ }^{71}$ F Rusagara 'The spread of "genocide ideology" within the Great Lakes region: challenges for Rwanda' in M Campioni and P Noack (eds) Rwanda Fast Forward (New York: Palgrave Macmillan, 2012) pp 213-227.

${ }^{72} \mathrm{~K}$ Ramakrishna Democratisation of Hate: The Spread of Al-Qaedaism, RSIS Commentaries 2014 No 17, available at www. rsis.edu.sg/wp-content/uploads/2014/07/CO04017.pdf; R Schulze 'Islamofascism: four avenues to the use of an epithet' (2012) 52 Die Welt des Islams 290.

${ }^{73} \mathrm{~J}$ Surowiecki The Wisdom of Crowds (New York: Doubleday, 2004).

${ }^{74}$ Cf O Khazan The Stupidity of the Crowd (29 July 2013), available at www.theatlantic.com/health/archive/2013/07/thestupidity-of-the-crowd/278188/.
} 
Table 1. Conceptual framework and overview of main topics

\begin{tabular}{lll}
\hline & $\begin{array}{l}\text { Determinants for the occurrence of } \\
\text { malicious legal transplants (a below) }\end{array}$ & $\begin{array}{l}\text { How malicious legal transplants } \\
\text { may be prevented (b below) }\end{array}$ \\
\hline $\begin{array}{l}\text { (i) The object of the } \\
\text { transplant }\end{array}$ & $\begin{array}{l}\text { Attractiveness of transplant in form and } \\
\text { substance }\end{array}$ & $\begin{array}{l}\text { Stopping or influencing underlying } \\
\text { ideas }\end{array}$ \\
\hline (ii) The transplant process & $\begin{array}{l}\text { Deficient law-making process and } \\
\text { influence of private parties }\end{array}$ & $\begin{array}{l}\text { Challenging ideas and power } \\
\text { imbalances }\end{array}$ \\
\hline $\begin{array}{l}\text { (iii) The dynamics in the } \\
\text { transplant country }\end{array}$ & $\begin{array}{l}\text { Anti-path dependency and power } \\
\text { dynamics }\end{array}$ & Improving resilience of legal system \\
\hline
\end{tabular}

\section{(a) Determinants for the occurrence of malicious legal transplants}

As we have seen, the object of a legal transplant can be legal rules, legal ideas or other elements of the legal system. ${ }^{75}$ Thus, the starting point for the following discussion is whether particular objects of transplants are more likely to be of a malicious nature. The subsequent discussion of the transplant process is related to the previous analysis as to why legal transplants occur. ${ }^{76}$ Finally, we consider the dynamics in the transplant country, as it was shown that the relationship between groups in society was often an important element in the examples of malicious legal transplants. ${ }^{77}$

\section{(i) The object of the transplant}

The object of the transplant can matter due to its form or its substance. Starting with the formal characteristics, the malicious legal transplant can be due to its combination of cultural and social factors. For example, in the scenarios of rules that stipulate racial discrimination, ${ }^{78}$ the precise legal text is less important than the spread of the underlying ideology. The occurrence of the legal transplant is therefore due to the success of this more general idea which, for example, can derive from the aim of one group in society to impose its moral and ethical standards on the society as a whole.

It can, however, also be the case that the malicious legal transplant is due to the precise legal codification. This form of such a legal transplant can occur where something which, originally, was a mere cultural norm has been codified by the origin country as a generally applicable law. For example, this can happen when a religious practice becomes a legal rule which applies to the entire population, including minority groups. Or, it can concern the regulation of particular consensual sexual acts which, originally, were merely seen as inappropriate. ${ }^{79}$ Subsequently, the codified rule can then easily be copied by other countries.

The substance of the transplant can also play a decisive role. Here too the reasons that account for the maliciousness of the transplanted legal idea can be the same ones that contribute to its occurrence. In particular, this can happen where the attractiveness of the idea is due to its detachment from reality. Such a case may be described as a situation where an idea 'seems too good to be true' - and indeed it is. For example, one may think about the Nazi/Fascist belief that racial characteristics are correlated with the virtue and character of human beings, or the view that sexual preferences are entirely a matter of choice. $^{80}$

Another attractive (as regards the transplantation) and malicious substantive factor can be the radical nature of the transplanted law. For example, the appeal of Wahhabi-based legal concepts in Indonesia may be explained by the way 'actors use Saudi Arabia to construct an imaginary ideal through which social and religious issues are contemplated and compared to apparent Indonesian

\footnotetext{
${ }^{75}$ See Section 1 (a) (i), above.

${ }^{76}$ See Section 1 (b) (i), above.

${ }^{77}$ See Section 1 (a) (ii), above.

${ }^{78}$ See the first example of Section 1 (a) (ii), above.

${ }^{79}$ See the second and third examples in Section 1 (a) (ii), above.

${ }^{80}$ See the first and third examples in Section 1 (a) (ii), above.
} 
"social corruption". ${ }^{81}$ This occurrence can also be due to the fact that, following insight from diffusion research, simple ideas spread more easily than complex ones. ${ }^{82}$ Here, thus, both the simplicity and the radicalism are attractive features for law makers since they enable them to brand all critics of the transplant as 'heretics'.

\section{(ii) The transplant process}

Turning to the relationship between origin and transplant countries, the negative outcome of malicious legal transplants appears to be counterintuitive: following the main narrative about the benefits of regulatory competition, one would usually expect that 'the best' laws survive. ${ }^{83}$ Such a positive outcome would also be in line with the view of a 'Darwinian' battle in a marketplace for good ideas. ${ }^{84}$

In this general debate there is, however, also the view that regulatory competition can lead to a 'race to the bottom'. ${ }^{85}$ This can also be relevant for legal transplants since - as in law making more generally ${ }^{86}$ - mistakes can happen in the transplantation of ideas. ${ }^{87}$ For example, it is possible that the cost-saving advantage of a transplant ${ }^{88}$ leads to a hasty adoption of a mistaken foreign model. It can also be the case that the law maker of the transplant country misjudges the character of the law since it follows the general belief that the laws from the origin country - say, a country of the same legal family with a distinguished legal tradition - are worth adopting. ${ }^{89}$

More specifically, however, malicious transplantations are, at least from the perspective of one of the participants, the result of a deliberate process. ${ }^{90}$ Here, as the general research on legal transplants has observed, the power relationship between the origin and the transplant countries plays an important role. ${ }^{91}$ More specifically, the adoption of the foreign idea can have the aim of creating or fostering an international alliance with the origin country. ${ }^{92}$ There can also be financial incentives, for example where the transplant country agrees to follow certain rules of the origin country in exchange for foreign aid supporting its education, healthcare etc. ${ }^{93}$

In addition, private interests often play a crucial role. ${ }^{94}$ Self-interested and strategic law makers may deliberately make use of malicious rules. Such legal rules may also be supported by powerful self-interested transnational groups, such as multinational corporations, religious organisations and political movements. Moreover, it can be a determinant that powerful private groups from the origin country successfully lobby for their position in the transplant country, ${ }^{95}$ for example aiming to reduce transaction costs or to establish cultural hegemony, ${ }^{96}$ depending on the preferences of the group in question.

\footnotetext{
${ }^{81}$ Chaplin, above n 23, p 217.

${ }^{82}$ See Section 1 (b) (iii), above.

${ }^{83}$ For the debate, see eg DC Esty and D Géradin (eds) Regulatory Competition and Economic Integration (Oxford: Oxford University Press, 2003).

${ }^{84}$ See Section 1 (b) (iii), above. For the notion of a 'marketplace of ideas' and its shortcomings, see also S Poole Rethink: The Surprising History of Ideas (New York: Random House, 2016).

${ }^{85}$ This phrase was coined by WJ Cary 'Federalism and corporate law: reflections upon Delaware' (1973-1974) 83 Yale Law Journal 663.

${ }^{86}$ See eg R Baldwin, M Cave and M Lodge Understanding Regulation (Oxford: Oxford University Press, 2nd edn, 2012) pp 68-82, on regulatory failures.

${ }^{87}$ Suggested by Carolan, above n 5 .

${ }^{88}$ See Section 1 (b) (i), above.

${ }^{89}$ Ibid. (countries often choosing the 'most legitimate model').

${ }^{90}$ See Section 1 (a) (i), above.

${ }^{91}$ Ibid.

${ }^{92}$ See the first example in Section 1 a (ii), above.

${ }^{93}$ See the second example in Section 1 a (ii), above.

${ }^{94}$ For private interest theories of regulation, see eg B Morgan and $\mathrm{K}$ Yeung An Introduction to Law and Regulation (Cambridge: Cambridge University Press, 2007) pp 43-53.

${ }^{95}$ For both, see the second example in Section 1 (a) (ii), above.

${ }^{96}$ See Section 1 (b) (i), above.
} 


\section{(iii) The dynamics in the transplant country}

Understanding the dynamic within the transplant country is crucial since, conventionally, one would assume that law is path-dependent: thus, in the present scenario, the expectation would be that countries retain their existing law and do not adopt ideas from abroad - and even less so if those are of a malicious nature.

However, there can be forces that overcome such path-dependencies. It is often said that law makers may have a 'pro-innovation bias', namely that 'anything new' is perceived as 'better than what has gone before and that adoption is more worthy of study than non-adoption or rejection'. ${ }^{97}$ A more specific rationale for malicious legal transplants can be that adopting them is in line with a general legal trend. For example, it may be argued that the adoption of conservative Islamic laws in countries in Africa and Asia is a continuation of the struggle to fully 'decolonise' from Western ideas.

It is, however, not only the force of such imagined views of modernity or identity that plays a role within the transplant country. It can also be the case that even rational actors accept dubious ideas. ${ }^{98}$ In the current context, such a situation can often arise when the interests of private parties are a decisive factor in the adoption of the malicious legal transplant. For example, a particular legal idea may be supported by powerful private groups (businesses, political parties, religious organisations etc) in the transplant country who use the foreign ideas in a strategic way in order to successfully lobby for their position.

In addition, reasons of political economy often play a crucial role. In the power dynamics within the transplant country, the foreign idea can be a useful rhetorical tool to support a particular line of reasoning. A frequent scenario, as evidenced by the examples, ${ }^{99}$ is that a majority group uses such an argument for the oppression of a country's minorities. Such a situation may be most likely in illiberal democracies, since the majority does not face corresponding accountability for its power. But there can be other situations too. For example, in non-democratic societies the adoption of the foreign idea may have the aim of using such ideas to suppress political opponents. ${ }^{100}$ It can also be the case that in a liberal democracy certain electoral rules contribute to a malicious legal transplant: for example, assume a situation where in a country with a first-past-the-post electoral system a party wins the election without having won the support of the majority of the population. Subsequently this party uses its power to entrench its position by way of disenfranchising parts of the population, say through rules of racial segregation. Malicious legal transplants are therefore possible in any political system.

\section{(b) How malicious legal transplants can be prevented}

Before addressing the question how malicious legal transplants can be prevented, it is important to consider which entities and persons may, in principle, be able to do so. The challenge is that, depending on the type of transplant, ${ }^{101}$ the state powers of both the origin and the transplant country may be the perpetrators in question. However, this section will suggest that prevention is, at least in some circumstances, possible by three broad groups. First, third countries and international organisations can try to exert influence on the origin and transplant countries. Secondly, within the origin and transplant countries, societal forces can play a role: thus, citizens, companies and interests groups can try to prevent malicious legal transplants. Thirdly, the current law makers of the origin and transplant countries can try to influence the decisions of future law makers, for example directly through constitutional rules or indirectly through changes in societal conditions. The following will elaborate on these means of prevention, based on the structure of the previous subsection, thus dealing with the object of the transplant, the transplant process and the dynamics in the transplant country.

\footnotetext{
${ }^{97}$ Greenhalgh et al, above n 62, p 10.

${ }^{98}$ Boudon, above n 65 .

${ }^{99}$ See all three examples in Section 1 a (ii), above.

${ }^{100}$ Possibly this was the case in the first example in Section 1 a (ii), above.

${ }^{101}$ See Section 1 a (i) and (b) (i), above.
} 


\section{(i) The object of the transplant}

The most direct way to prevent a malicious legal transplant would be to stop it at its origins. In principle, it may be possible to pursue such a strategy; however, as will be shown, it can also be problematic or ineffective.

In some cases, third countries and international organisations may want to intervene in the origin country. For example, the situation indicated in the first example ${ }^{102}$ ended with the defeat of Nazism and Fascism in WWII. Of course, it did not eliminate racist ideas - and military campaigns would not be feasible for each spread of a malicious idea. Economic sanctions are another means at the international level. A law-based strategy that some third countries can pursue is to have laws with extraterritorial effects in order to hinder the flow of certain ideas. For example, a country where particular social media companies (Twitter, Facebook etc) are located can regulate their standards with effect to other countries. ${ }^{103}$

The inherent problem is that, while in extreme cases international or third-country intervention may be justified, in principle, the national sovereignty of the origin country needs to be respected. ${ }^{104}$ Practically, it may also be said that any such measure cannot fully eliminate malicious legal transplants: indeed, malicious ideas do not seem to die but are frequently reborn, as the history of racist ideas exemplifies. $^{105}$

Related possibilities and problems are likely for activities by the other two groups that can react to the object of a malicious legal transplant. The societies of the origin and transplant country can try to oppose the idea. In addition, following from the determinants of occurrence identified in the previous section, ${ }^{106}$ it is not only the idea that matters but also its codification, abstraction and radicalisation which citizens, interest groups and other constituencies in the society can oppose. The problem is that the scenarios discussed here are about situations where the law makers of the countries support the idea. So in liberal democracies the precise boundaries of legitimate powers of minority groups need to be identified, ${ }^{107}$ while in other regimes the main question is whether effective political campaigns against the wishes of the government are possible at all. ${ }^{108}$

Current law makers trying to prevent malicious decisions of future law makers can directly address the idea in question. For example, law makers in some countries criminalise certain opinions, symbols and publications, say, in order to prevent the (re-) emergence of racist ideas. ${ }^{109}$ A more indirect strategy can, for instance, concern changes to the national school curriculum or other questions of school and university education. But here too the ideas may continue to exist underground. Moreover, at least in liberal societies, it would usually be expected that law makers are accountable to society and do not try to shape the society's views according to their preferences.

Overall, this shows the limited means of fully stopping a particular malicious idea. More promising are ways to influence ideas and how they evolve into a possible object of a malicious legal transplant, though this too is certainly not an easy endeavour. It also goes beyond the scope of what legal scholars

\footnotetext{
${ }^{102}$ See Section 1 a (ii), above.

${ }^{103}$ For the discussion, see eg JM Moringiello and WL Reynolds 'The new territorialism in the not-so-new frontier of cyberspace' (2014) 99 Cornell Law Review 1415; Symposium issue on Extraterritoriality and EU Data Protection (2015) 5(4) International Data Privacy Law.

${ }^{104}$ This is a frequent objection against laws with an extraterritorial effect; see eg J Kirshner 'Why is the U.S. abdicating the policing of multinational corporations to Europe? Extraterritoriality, sovereignty, and the alien tort statute' (2012) 29 Berkeley Journal of International Law 259.

${ }^{105}$ See GM Fredrickson Racism: A Short History (Princeton, NJ: Princeton University Press, 2002).

${ }^{106}$ See Section 2 (a) (i), above.

${ }^{107} \mathrm{Eg}$ in terms of free speech or the right to public protest; see eg D Mead The New Law of Peaceful Protest (Oxford: Hart Publishing, 2010).

${ }^{108}$ See eg L Chua 'Pragmatic resistance, law, and social movements in authoritarian states: the case of gay collective action in Singapore' (2012) 46 Law \& Society Review 713.

${ }^{109}$ See eg MJ Bazyler Holocaust Denial Laws and Other Legislation Criminalizing Promotion of Nazism GPN Genocide Year in Review 2009, available at www.ihgjlm.com/wp-content/uploads/2016/01/Holocaust-Denial-Laws.pdf.
} 
usually consider in their research as it requires an understanding of the cultural and societal determinants and dynamics underlying malicious ideas.

\section{(ii) The transplant process}

A common feature of interventions in the transplant process is that it challenges the success of the malicious ideas. This approach, therefore, follows the spirit that 'little can be borrowed, but much can be learned, from foreign law ${ }^{110}$ - and that indeed 'even apparently vicious and disingenuous ideas can lead to illuminating rebuttal ${ }^{111}$ and that foreign ideas too may be used to show what should not be done. ${ }^{112}$ Of course, sometimes a transplant had already occurred in the distant past, for example the colonial transplants, ${ }^{113}$ but even here such information can be useful as it can lead to the reversal of a particular foreign and 'malicious' legal idea.

More specifically, for third countries and international organisations the main approach may be to present benevolent counter-models that weaken the malicious idea. In such a 'battle of ideas', therefore, 'applied comparative law ${ }^{\text {'114 }}$ becomes relevant. In line with a modern contextual understanding of comparative law, it is important to consider how far the contextual differences across countries influence the suitability or unsuitability of foreign ideas. ${ }^{115}$ Such considerations also play a crucial role for the way international organisations such as the UN and the World Bank influence the choice of legal rules on a global scale. ${ }^{116}$

Another problem to consider is the frequent power imbalance between the origin and the transplant country. ${ }^{117}$ Thus, politically and/or economically, the transplant country may feel that it has no choice but to follow the stronger origin country. Here, then, third countries and international organisations can try to prevent, or reverse, malicious legal transplants by way of directly challenging the views of the origin country or by providing support to the weaker transplant country so that it becomes easier to withstand the pressure of the origin country.

With respect to societal forces, it depends on the country in question to what extent society can influence the transplant process. It has already been mentioned that businesses, lobby groups and religious organisations can be a driving force behind malicious legal transplants. ${ }^{118}$ Thus, such groups may, in some cases, also be able to channel the content and form of the transplant in a positive direction.

How far current law makers should prospectively provide guidance on choices of foreign models has recently become relevant in the US. The state of Oklahoma attracted considerable attention by explicitly prohibiting state courts from considering 'the legal precepts of other nations or cultures', specifically mentioning international law and Sharia law; other states have passed or are debating measures with similar intentions. ${ }^{119}$ The apparent threat is that such a generic position in the search for good legal ideas is based on prejudiced views about certain foreign laws. Thus, it is suggested that for judicial comparative law it is preferable to provide judges with the training and tools in order to enable them to make an informed choice from solutions adopted by courts elsewhere in the

\footnotetext{
${ }^{110} \mathrm{E}$ Rubin 'Administrative law and the complexity of culture' in A Seidman, R Seidman and J Payne (eds) Legislative Drafting for Market Reform: Some Lessons from China (Hampshire: Macmillan, 2000) p 108.

${ }^{111}$ S Poole 'Why bad ideas refuse to die' The Guardian 28 June 2016, available at www.theguardian.com/science/2016/jun/ 28/why-bad-ideas-refuse-die.

${ }^{112}$ Called 'negative fertilisation' by Cohn, above $\mathrm{n} 44$.

${ }^{113}$ See the third example in Section 1 a (ii), above.

${ }^{114}$ See Siems, above n 15, pp 27-28, 233-234.

${ }^{115}$ See above $\mathrm{n} 2$.

${ }^{116}$ See eg Trebilcock and Prado, above n 51, pp 7-12, 78-80, and Section 1 (b) (i), above.

${ }^{117}$ See the second example in Section 1 a (ii), above, as well as 1 (b) (i) and 2 (a) (ii), above.

${ }^{118}$ See Section 2 (a) (ii), above.

${ }^{119}$ For the debate, see eg S Islam 'The negative effects of ill-advised legislation: the curious case of the evolution of anti-Sharia law legislation into anti-foreign law legislation and the impact on the CISG' (2013/14) 57 Howard Law Journal 979; PM Venetis 'The unconstitutionality of Oklahoma's SQ 755 and other provisions like it that bar state courts from considering international law’ (2011) 59 Cleveland State Law Review 189.
} 
world. ${ }^{120}$ Likewise, for legislators, the appropriate guidance is that law makers should conduct wide consultations on diverse foreign models in order to make the right choices.

As a result, it can be seen that there are some means to intervene in the transplant process: third countries and international organisations can challenge malicious ideas and power imbalances, and societal groups of the transplant country (including legal scholars) can try to shape the political debate. Details on their success depend on the power relationship between the relevant organisations, states and groups - akin to other research about the relationship between law and politics, for example, on the possible influence of 'subaltern' forces in the age of globalisation. ${ }^{121}$

\section{(iii) The dynamics of the transplant country}

Since the transplant country often tends to be politically or economically weak in comparison to other countries, it seems possible for third countries or international organisations to attempt to influence the transplant country's choice of models. As noted in the previous sections, reasons of national sovereignty may provide a counter-argument, but it can also be said that 'meddling' in the transplant country's affairs is justifiable as far as the aim is to prevent a malicious transplant from another country. For example, if Saudi influence pressurises countries to introduce rules that discriminate against non-Muslims, ${ }^{122}$ third countries can try to diffuse this pressure, for example through bargaining over investment treaties or foreign aid.

One may also hope that the society of the transplant country would have a strong voice in preventing malicious legal transplants:

Free speech has tools to manage the flow of ideas. Ideally you want to encourage the spread of good ideas and discourage the spread of bad ones. Free societies rely on their ability to isolate, ostracize, boycott, ignore, not read, not pass on, social exclusion, and marginalization to prohibit the spread of bad ideas. ${ }^{123}$

This suggestion assumes an active position of citizens in the way ideas - including legal ones - are chosen. Moreover, it is premised on the condition that free speech is sufficiently protected in the society in question. It is therefore likely that liberal democracies are less often subject to the malicious legal transplant than other political systems.

More generally, a number of further observations can be made for the way the current law maker of the transplant country can influence the dynamics of the transplant country in the future. Law makers may provide special protection of particular values, thereby restricting future law makers. For example, in many countries, the constitutional protection of human rights means that these rules can only be amended by future law makers through special procedures. In addition, some countries' constitutions contain 'eternity provisions' so that certain rules cannot be changed at all. Consider, for instance, that the German constitution protects human dignity in such a way, based on the explicit rationale to prevent a repeat of the Nazi atrocities. ${ }^{124}$

It also makes a difference how the law maker of the transplant country shapes the structure of its political system. Apart from complete shifts in political models, changes in detail matter too. The main examples of malicious legal transplants were about situations where law makers sided against

\footnotetext{
${ }^{120}$ E Mak Judicial Decision-Making in a Globalised World (Oxford: Hart Publishing, 2013). See also Gelter and Siems, above n 12.

${ }^{121}$ For the latter, see eg B de Sousa Santos and CA Rodriguez-Garavito 'Law, politics, and the subaltern in counterhegemonic globalization' in B de Sousa Santos and CA Rodriguez-Garavito (eds), Law and Globalization from Below: Towards a Cosmopolitan Legality (Cambridge: Cambridge University Press, 2005) pp 1-26.

${ }^{122}$ See the second example of Section 1 a (ii), above.

${ }^{123}$ Blog Post Should We Create a Critical Idea Permeability Index? (10 July 2013), available at www.thenakedscientists.com/ forum/index.php?topic $=48240.0$.

${ }^{124}$ Arts 1(1), 79(3) of the German Basic Law. For examples from other countries, see JI Colón-Riós Weak Constitutionalism: Democratic Legitimacy and the Question of Constituent Power (London: Routledge, 2012 ) p 67.
} 
particular groups in society. ${ }^{125}$ Thus, it is vital to not simply provide majoritarian representation but also rules that protect all members of society. Depending on the society in question, this may, for example, mean strong minority rights, mandatory participation of all groups in the government, a federal structure or other multi-level participation rights. ${ }^{126}$

Consequently, it is not the case that the transplant country is necessarily helpless as regards the risks of malicious legal transplants. The main lesson is that it is possible to improve the resilience of the legal and political system. Of course, having a sound constitutional structure is not merely relevant in order to prevent malicious legal transplants; thus, it also shows that the debate about such design choices needs to balance these and other policy considerations.

\section{Conclusion}

Recent research on legal transplants has often been concerned with the undertaking to choose and design legal transplants in an intelligent way. ${ }^{127}$ This research has a positive dimension insofar as it tries to identify how, technically, certain foreign rules can most effectively be transplanted. However, it often also has a normative dimension as it tries to promote transplants that work well and should therefore be suggested to law makers.

By contrast, the current paper started with a normative issue - the idea that legal transplants can be malicious - while it also had a positive dimension - exploring why these transplants occur. In its main parts it suggested three paradigmatic examples of such a transplant, discussed its research context, identified reasons for its occurrence and presented ways in which such transplants can be prevented. Of course, there is no 'silver bullet' against malicious ideas and laws. Rather, any solution has to identify precisely at which stage and with which tools intervention in the determinants of the malicious legal transplant is possible, for example, whether it is feasible to challenge the underlying idea, to counteract the pressure by the origin country or the influence of the power dynamics within the transplant country. ${ }^{128}$

These suggestions to prevent legal transplants may sound out of date if we assume that the legal world moves in the direction of a global convergence of legal systems. ${ }^{129}$ However, it was not the intention of this paper to suggest that laws should never converge - as indeed it did not aim to suggest that legal transplants cannot also be a tool for 'better law'. ${ }^{130}$ As a recent book by the economic historian Deirdre McCloskey explains, good ideas have been a major determinant for prosperity around the world. ${ }^{131}$ Good ideas can also be foreign ideas. There is no reason to believe that societies benefit from intellectual isolation. Rather, it can be shown that foreign legal ideas may even be 'overfitting' in the sense that they work better in the transplant country than in the country of origin. ${ }^{132}$

As a consequence, the choice and design of legal transplants is indeed crucial. This requires knowledge and understanding of both the technical aspects of the transplant and its normative implications. It also means that scholars of legal transplants need to consider various fields of research such as

\footnotetext{
${ }^{125}$ See Section 1 (a) (ii), above.

${ }^{126}$ See eg M Mutua 'The Iraq paradox: minority and group rights in a viable constitution' (2006) 54 Buffalo Law Review 927. See also the discussion in regulation studies: eg Baldwin et al, above n 86, pp 338-355, 373-387; Morgan and Yeung, above n 94, pp 221-280.

${ }^{127}$ See eg G Frankenberg 'Constitutional transfer: the IKEA theory revisited' (2012) 8 International Journal of Constitutional Law 563; H Xanthaki 'Legal transplants in legislation: defusing the trap' (2008) 57 International and Comparative Law Quarterly 659.

${ }^{128}$ See Section 2 (b), above.

${ }^{129}$ For the discussion see Siems, above n 15, pp 262-279.

${ }^{130}$ However this may be defined. See M Siems 'Bringing in foreign ideas: the quest for "better law" in implicit comparative law’ (2014) 9 Journal of Comparative Law 119.

${ }^{131} \mathrm{DN}$ McCloskey Bourgeois Equality: Ideas, not Capital or Institutions, Enriched the World (Chicago, IL: University of Chicago Press, 2016).

${ }^{132} \mathrm{M}$ Siems 'The curious case of overfitting legal transplants' in M Adams and D Heirbaut (eds) The Method and Culture of Comparative Law: Essays in Honour of Mark Van Hoecke (Oxford: Hart Publishing, 2014) pp 133-146.
} 
comparative law, jurisprudence, law and regulation, and law and development, as has been attempted in this paper. It is suggested that this cross-sectional nature makes research on legal transplants a demanding but also a stimulating endeavour. 